\title{
Vilniaus miesto viešųjų erdvių sistema
}

\section{Tautvydas Bokmota,}

\section{Simonas Šabanovas}

Vilniaus universitetas,

M. K. Čiurlionio g. 21,

03101 Vilnius, Lietuva

El.paštas: t.bokmota@gmail.com; simonas.sabanovas@gf.vu.lt
Bokmota T., Šabanovas S. Vilniaus miesto viešųjų erdvių sistema. Geologija. Geografija. 2018. T. 4(4). ISSN 2351-7549.

Straipsnyje supažindinama su viešųjų erdvių sistemos tyrimais, viešosios erdvès samprata ir viešujų erdvių sistemos koncepcija. Ypatingas dèmesys skiriamas Vilniaus miesto viešųjų erdvių sistemos, jos ypatumų bei probleminių arealų analizei ir aptarimui.

Nustatyta, kad Vilniaus miesto viešųjų erdvių sistema teritoriniu požiūriu yra susiformavusi netolygiai. Vienose Vilniaus miesto dalyse, pavyzdžiui, senamiestyje, viešųjų erdvių sistema yra išvystyta, didelis plotas viešųjų erdvių, jų tinklas yra tankus, o kitose Vilniaus miesto dalyse, pavyzdžiui, „,miegamuosiuose" priemiesčiuose ar sovietinio laikotarpio gyvenamuosiuose rajonuose, viešųjų erdvių tiek kiekis, tiek plotas yra mažesnis, jaučiamas jų trūkumas.

Raktažodžiai: viešoji erdvė, viešųjų erdvių sistema, Vilniaus miestas, grafų teorija

\section{IVADAS}

Nors mokslinių ar publicistinių straipsnių apie viešąsias erdves bei jų problemas yra daug, vis dèlto šia tematika pateikiamos nuomonès, kritika ar diskusijos vyksta viena kryptimi - i viešąsias erdves yra žvelgiama kaip i̇ pavienius objektus, tačiau ne kaip i̇ vieningą, tampriai susijusią sistemą. Šis sisteminio požiūrio nebuvimas, kuris leistų išvengti, pavyzdžiui, netolygaus viešųjų erdvių pasiskirstymo mieste, lemia, kad gyvenimo bei aplinkos kokybė vienuose teritorijų kompleksuose yra geresnè, kituose - prastesnè. Dèl to susiduriama su ịvairiais iššukiais - nuo būstų teritorijų kompleksuose su prastai išvystyta viešųjų erdvių sistema patrauklumo mažejimo iki socioekonominèmis sąlygomis pagrịstų getų susidarymo, kai turtingesni gyventojai renkasi teritorijų kompleksus (mikrorajonus) su daugiau viešųjų erdvių, daugiau gamtos, malonesne šeimai bei gyvenimui aplinka, o socialiai jautri ar turinti finansinių sunkumų visuomenès dalis lieka gyventi nepatraukliuose mikrorajonuose su prastai išvystyta viešųjų erdvių infrastruktūra arba kur jų apskritai trūksta.

Viešųjų erdvių sistema kaip atskiras mokslinio tyrimo objektas tiek užsienio, tiek Lietuvos mokslininkų aptariamas ir tyrinejjamas gana retai. Kaip teigia T. Grunskis (2013), moksliniai darbai Lietuvoje, vienaip ar kitaip gvildenantys ši klausimą, yra labai fragmentiški. Tokia padètis galbūt galejo susiklostyti dèl viešųų erdvių sistemos problemos urbanizuojant vietoves ir sampratos neaiškumo. Vis dèlto yra darbų, kurie vienokiu ar kitokiu aspektu nagrinėja viešųjų erdvių sistemas. Užsienyje šie darbai labiau skirti viešosios erdvès vaidmeniui sistemoje atskleisti, o Lietuvoje labiau orientuoti i pačių sistemų tyrinèjimą. Daugiausia prie šių tyrimų prisidejo T. Kačerauskas (2011), tyręs miesto kultūrines erdves, M. Burinskienè ir R. Ušpalytė-Vitkūnienė (2006), R. Malakauskienė ir V. Gerikienè (2012), analizavę želdynus 
viešosiose erdvèse, P. Juškevičius (2002, 2003, 2006), V. Stauskas (2007) ir T. S. Butkus (2011), tyrę miestų planavimo morfologinius objektus. Daugiausia šioje srityje yra nuveikę architektai, kraštovaizdžio architektai, urbanistai ir menotyrininkai, t. y. meno krypties atstovai.

Straipsnio tikslas - atskleisti Vilniaus miesto viešųjų erdvių sistemos ypatumus. Siekiant šio tikslo buvo išsikelti ir igyvendinti tokie uždaviniai:

1) susisteminti ankstesnius viešųų erdvių sistemų tyrimus;

2) parengti viešųjų erdvių sistemų tyrimo metodiką;

3) i̇vertinti Vilniaus miesto viešųjų erdvių sistemą;

4) pateikti Vilniaus miesto viešųjų erdvių sistemos probleminius arealus.

Šio tyrimo autoriai pristato viešųų erdvių sistemų tyrimus, viešosios erdvès sampratą, viešųjų erdvių sistemos koncepciją. Darbas supažindina su Vilniaus miesto viešųjų erdvių sistema, jos ypatumais ir probleminiais arealais.

\section{VIEŠOSIOS ERDVĖS SAMPRATA}

Kol kas nèra vieningos ir išgrynintos viešosios erdvès sampratos. Skirtingų sričių specialistai ją suvokia ir pateikia labai skirtingai (Grunskis, 2013). Vis dèlto viešoji erdvė yra apibrèžta Lietuvos Respublikos teritorijų planavimo isstatyme, tai gali būti kaip tam tikras orientacinis taškas.

Viešoji erdvé, kaip nusako Lietuvos Respublikos teritoriju planavimo ístatymas, yra gyvenamosios vietovès urbanizuotos teritorijos erdvinès struktūros elementas, skirtas visuomenès bendriesiems interesams (Lietuvos Respublikos teritorijų..., 2013). Tai yra gana trumpa, tačiau labai kompleksiška viešosios erdvès apibrèžtis. Ši apibrèžtis tik paaiškina, kas yra viešoji erdvè, tačiau neịvardija, kokius elementus ji apima. J. Gehlas apibendrina, kad viešoji erdvè yra visa erdvè tarp ivvairios paskirties pastatų (2011). Tai prisideda prie bendro sutarimo, pavyzdžiui, ar miesto arba miško parkai yra viešoji erdvè. V. Stauskas (2006) ir K. Jakovlevas-Mateckis (2006) teigia, kad viešoji erdvè yra miesto parkai. Vis dèlto daugelis autorių miško parkų nelaiko viešąją erdve.

Išgrynintos viešosios erdvès sampratos nebuvimas lemia skirtingas autorių interpretacijas.
Pavyzdžiui, T. S. Butkus, kalbèdamas apie viešąją erdvę, užsimena apie ją kaip apie „vietą, kurioje kiekvienas pilietis gali mėgautis sambūviu su kitais žmonėmis bei atstovauti kolektyviam ir bendram interesui, nenustelbdamas ar nenaikindamas jų ịvairovès“. Taip viešosios erdvès sąvoka tampa vis labiau „išplaukusi“, nes privatūs interesai ir erdvès sutapatinamos su bendruomene (Mitchell, 1995). Panašus ir T. S. Butkaus apibrèžimas apie viešąją erdvę: „Miestų teorijoje viešoji erdvè visu pirma yra suprantama kaip vienas iš svarbesnių urbanistinès struktūros lygmenų, apimančių neužstatytas ir žaliąsias miesto erdves“ (2007: 92). Vèliau autorius taip pat išskiria pagrindinius viešųjų erdvių tipus: gatvè, pasažas, krantinè, aikštè, skveras ir parkas. Kaip matome, autorius vadovaujasi gana tradicine viešosios erdvès samprata ir įvardija, kas yra laikoma viešąją erdve bei kokie yra jos elementai.

Anot T. Grunskio, „neretai viešąa erdve yra vadinami objektai ir urbanistiniai dariniai, kurie iki šiol nebuvo suprantami kaip tradicine miesto viešoji erdvë“ (2009: 137). Viešosios erdvès apibrèžtis, kurioje nèra išskiriami viešosios erdvès elementai, panašiai pateikiama ir R. Buivydo. Jis teigia, kad „urbanistikoje viešosiomis erdvėmis vadinama ta urbanistinès erdvès lauko dalis, kuri paprastai yra apsupta gatvių ir takų tinklo" (Buivydas, 2010: 133).

R. Buivydas straipsnyje „Viešųjų erdvių transformacija Lietuvos miestuose“ mini, jog "kai kurie autoriai patikslina, kad normatyviniu požiūriu erdvès laikomos viešosiomis, jei jas suteikia ir prižiūri vietos valdžia, jei jos yra atviros ir jomis gali be apribojimu pasinaudoti visi miesto bendruomenès nariai“ (2010: 133). Šiuo atveju autoriai apsiriboja viešosios erdvès apibrèžimu, tačiau ne jos elementų ịvardijimu.

Viešosios erdvès samprata, kaip ir tipologija, nuolatos kinta. Viešosioms erdvėms yra priskiriami tie objektai, kurie iki tol nebuvo laikomi viešosiomis erdvėmis (kadangi daugumos jų tiesiog anksčiau nebuvo). Pavyzdžiui, dideli visuomeniniai pastatai - prekybos ir pramogų centrai, tampantys viešųjų erdvių pakaitalu. Šiandien juose yra sutelkiama daug tradicinių miesto centrui būdingų funkcijų ir net viešųjų erdvių, pavyzdžiui, prekybos gatvių, miesto aikščių ir panašių erdvių. Šiandien tai yra naujosios viešosios erdvès, dubliuojančios senąsias tradicines viešąsias erdves 
ir jų funkcijas. Šie procesai gali vesti prie laikinos tradicinių viešujų erdvių atrofijos. Vienas iš ryškiausių pavyzdžių yra Laisvès alèja Kaune (Grunskis, 2009). Taigi nors viešosios erdvès gali būti sukurtos siekiant patenkinti visuomenès poreikius, tačiau dèl visuomenès veiksmų jų svarba gali sumenkti ar net išnykti.

Išanalizavus skirtingų autorių darbus ir literatūros šaltinius, buvo sudaryta lentelè (1 lentelè). Joje pateikti ìvairūs šaltiniai ir įvardyti viešųjų erdvių tipai. Paaiškejjo, kad daugumoje šaltinių (iš 8 šaltinių 8 ir 7) viešąja erdve yra laikoma aikšte, skveras, gatve ir parkas. Pastarasis visuose šaltiniuose buvo įvardytas kaip viešoji erdvé, o lietuviškoje literatūroje, ypač kraštovaizdžio mokslų atstovų, pavyzdžiui, kraštovaizdžio architektų, dažnai priskiriamas želdynams ir nèra laikomas viešąja erdve. Tačiau, kaip teigia T. S. Butkus, „želdynai tèra tik urbanistinès struktūros elementų grupe“" (2009), tad parkas turètų būti laikomas viešąją erdve.

T. S. Butkus atkreipia dèmesí, kad yra skirtingo intensyvumo raiškos viešosios erdvès, kurios yra skirtingo lygio ir gali būti klasifikuojamos it pasaulinès, regioninès, bendramiestinès ir vietinès reikšmès (2011). Tai pabrèžia klasifikavimo reikšmę ir galimybę net miesto erdvejje išskirti nevienodo reikšmingumo ir poveikio zonos viešąsias erdves.

Kiti autorių įvardyti viešųjų erdvių tipai (žr. 1 lentelę) yra kur kas rečiau apibrèžiami kaip viešosios erdvès. Likusios viešosios erdvès buvo išskirtos tik viename ar dviejuose šaltiniuose. Tai apima tokius jų tipus: šaligatvị, pasažą, krantinę,

\section{1 lentelè. Iš skirtingų šaltinių išskirti viešųjų erdvių tipai (panašūs tipai ir potipai sugrupuoti)}

Table 1. Types of public spaces according to different sources (similar types and subtypes grouped)

\begin{tabular}{|c|c|c|c|c|c|c|c|c|c|c|c|c|c|c|c|}
\hline $\begin{array}{l}\text { Viešųjų erdvių tipai } \\
\text { Types of Public Spaces } \\
\text { Šaltinis } \\
\text { Source }\end{array}$ & 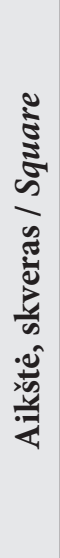 & 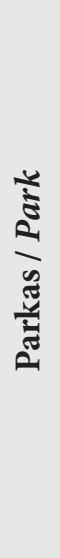 & $\frac{\varpi}{\infty}$ & 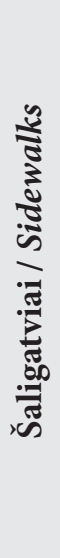 & 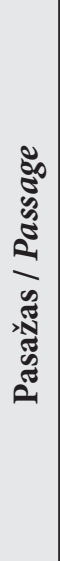 & 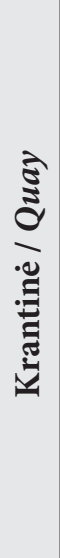 & 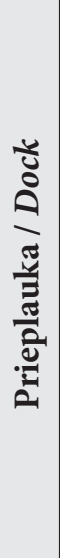 & 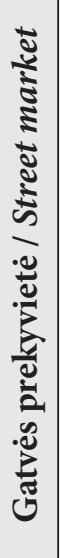 & 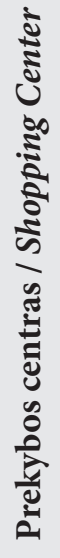 & 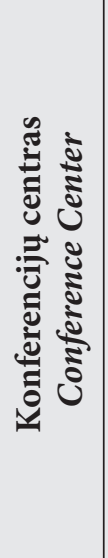 & 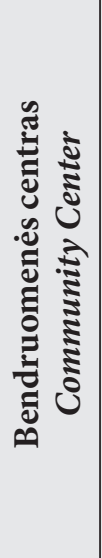 & $\begin{array}{l}\frac{2}{0} \\
0 \\
0 \\
\frac{1}{1} \\
\frac{0}{0} \\
1\end{array}$ & 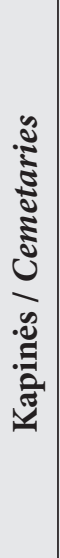 & 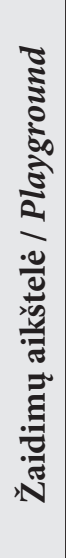 & 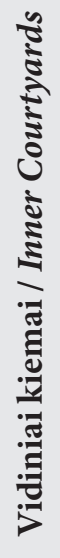 \\
\hline $\begin{array}{c}\text { Amerikos planavimo asociacija } \\
\text { American Planning Association, } 2017\end{array}$ & + & + & & & & & + & & + & + & & + & & & \\
\hline UNESCO, 2017 & + & + & + & + & & & & & & & & & & & \\
\hline $\begin{array}{l}\text { J. Rowntree fondo studija „Viešujų } \\
\text { erdvių socialinè verte“" / J. Rown- } \\
\text { tree Foundation publication “The } \\
\text { Social Value of Public Spaces”, } 2007\end{array}$ & & + & + & & & & & + & + & & + & & & + & + \\
\hline $\begin{array}{l}\text { Visuomenines geografijos žodynas } \\
\text { The Dictionary of Human Geography, } \\
2009\end{array}$ & + & + & + & & & & & & & & & & & & \\
\hline T. S. Butkus, 2007 & + & + & + & & + & + & & & & & & & & & \\
\hline $\begin{array}{l}\text { J. Kamičaitytė-Virbašienè, } \\
\text { A. Narvydas, } 2013\end{array}$ & + & + & & + & & & & & & & & & + & & \\
\hline $\begin{array}{l}\text { I. Gražulevičiūtè-Vileniškè, } \\
\text { A. Ražauskaitè, L. Ažukaité, } \\
\text { V. Bartininkaitė, L. Kulbokaitė, } \\
\text { J. Kameneckas, } 2011\end{array}$ & + & + & & & & & & & & & & & + & & \\
\hline T. S. Butkus, 2009 & + & + & + & & + & + & & & & & & & + & & \\
\hline J. Gehl, B. Svarre, 2013 & + & + & + & + & & & & + & + & & & & & & \\
\hline
\end{tabular}


kapines, žaidimų aikštelę, vidinius kiemus, prieplauką, gatvės prekyvietę, prekybos centrą, konferencijų centrą, bendruomenès centrą ir fojè.

Taigi pagrindinėmis viešosiomis erdvèmis šiame darbe yra laikoma aikštè, skveras, gatvè ir parkas. Kapinès, žaliosios jungtys ir kai kurios kitos viešosios erdvès taip pat gali būti laikomos viešosiomis erdvėmis, kadangi jos yra aptariamos tekstineje „Vilniaus miesto savivaldybès teritorijos bendrojo plano iki 2015 metų" dalyje, skirtoje gamtos vertybėms, želdynams ir viešųjų erdvių sistemai Vilniaus mieste, ar pateikiamos šio dokumento brěžiniuose. Tuo tarpu kalbant apie viešųų erdvių sistemos koncepciją šiame darbe yra vadovaujamasi T. Grunskio suformuluotu viešųjų erdvių sistemos apibūdinimu: „viešųjų erdvių sistema yra tarpusavyje susijusių miesto viešuju erdvių struktūra, kuriai priklauso visos šios erdvès (aikštès, gatvès, parkai) ir jų potipiai; ji yra susijusi funkciniais ir morfologiniais ryšiais ir veikia kaip darni visuma tam tikroje miesto dalyje arba visame mieste" (2013: 131). Ši autoriaus suformuluota viešųjų erdvių sistemos samprata dera su anksčiau šiame darbe pateikta viešosios erdvès samprata.

\section{DARBO METODIKA}

Darbe panaudoti teoriniai ir empiriniai tyrimo metodai. Visų pirma išryškinti skirtingi viešosios erdvès sampratos aspektai, viešųjų erdvių tipologija ar viešųjų erdvių sistemos koncepcija, atlikta literatūros analizè. Itvertinus teisinès ir mokslinès literatūros šaltinius, buvo ịvardyti ir apibrèžti populiariausi struktūriniai objektai, sudarantys viešųjų erdvių sistemą. Dažniausiai minimi tokie elementai kaip aikšte, skveras, gatvè, krantinè (žalioji jungtis arba upè), parkas, kapinès. Tai išsiaiškinta susisteminus skirtingų autorių siūlomas viešosios erdvès sampratas. Parodyta, kurie elementai yra dažniausiai laikomi viešosiomis erdvèmis. Vèliau juos buvo pasirinkta nagrinèti kaip pagrindinius viešųjų erdvių sistemos elementus.

Empirinei daliai pasirinktas tyrimo objektas yra Vilniaus m. sav., joje nagrinèta viešųjų erdvių samprata. Vilnius, kartu su Grigiškèmis ir Naująja Vilnia, yra svarbiausias Lietuvos miestas, kurio planavimas paveikia didžiausias bendruomenes. Tai galima vertinti kaip atvejo analizę, kurios re- zultatus būtų galima panaudoti analizuojant daugelị pasaulio miestų.

Kartografinès dalies brèžinių informacija buvo gauta iš Vilniaus m. sav. bendrojo plano grafinès dalies (Vilniaus miesto savivaldybès teritorijos bendrasis planas iki 2015 metų, 2018) ir geoportal.lt duomenu (ORT10LT - Lietuvos Respublikos teritorijos M 1:10 000 (c) skaitmeninis rastrinis ortofotografinis žemèlapis, 2016). Išvestinis Vilniaus miesto viešųjų erdvių sistemos žemèlapis (viešosios erdvès atspindètos plotais) buvo parengtas pasinaudojus ArcMap 10.3.1. (c) programine įranga.

Siekiant atskleisti sąsajas ir procesus, vykstančius tarp viešųjų erdvių, buvo pasirinkta kartografini metodą papildyti kompleksiniu tyrimo metodu - grafu teorija. Ji buvo aktyviai taikyta LUBFS (the Centre for the Land Use and Built Form Studies) centre tiriant ịvairias sąsajas (Ratti, Raydan, Steemers, 2003). Pritaikius šiuos (grafuc teorijos ir kartografinio metodo derinimą) metodus, buvo sukurta Vilniaus miesto viešųjų erdvių sąsajų schema. Schemai nubraižyti ir viešųjų erdvių plotinèms reikšmèms bei tipams perteikti skirtingomis erdvinèmis figūromis (tiek plotu, tiek forma) buvo pasirinkta CorelDRAW X7() programine įranga, o idejjiniu pagrindu tapo funkcinio zonavimo pavyzdžiai (Kavaliauskas, Šabanovas, 2011). Taigi skirtingo tipo viešoji erdvè pavaizduota skirtingo dydžio ir formos ženklu, o jų sąsajos linijomis, kad būtų atspindètos ne tik viešųjų erdvių buvimo vietos, bet ir jų vidinè struktūra bei procesiniai srautai seniūniju teritorijose.

Siekiant įvertinti skirtingų lygių ir kompleksų viešųjų erdvių trūkumą Vilniaus m. sav., buvo panaudota išvestinè sociologinè Wallersteino teorija (Gruževskis, Šabanovas, 2017) apie periferijas, kvaziperiferijas ir branduolius.

Čia mažosios struktūrinès viešųjų erdvių dalys buvo sujungtos i aukštesnio lygio (1 pav.) struktūras, o jos dar ị stambesnius darinius. Taip buvo atspindètos įvairaus dydžio viešųjų erdvių dalių struktūros - nuo mažiausių iki stambiausių, išskiriant ir viešųjų erdvių „aglomeracijas“, kurios buvo apibrěžtos kaip branduoliai. Šie branduoliai išskirti taikant kartografinị ir eksperimentinị vertinimą.

Siekiant apibendrinti Vilniaus miesto viešųjų erdvių sistemą, buvo remtasi atskirų seniūnijų 
duomenimis. Pateiktos rekomendacijos apie skirtingų tipų viešųjų erdvių trūkumus šiose posistemėse. Viešųų erdvių susitelkimo teritorijos buvo sudarytos išskiriant vizualinius klasterius; jų neapimančios teritorijos atspindi viešųjų erdvių trūkumo zonas.

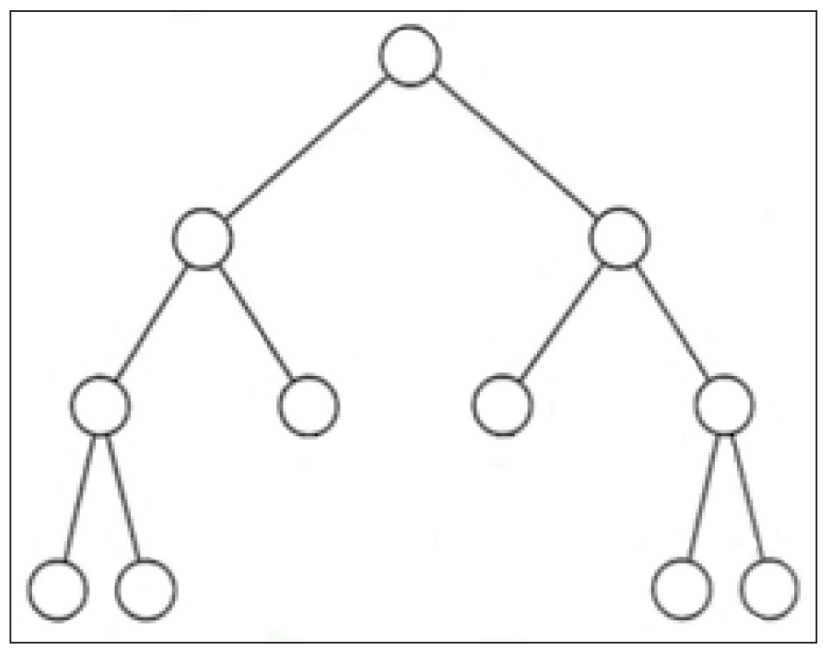

1 pav. Skirtingo lygio grafo pavyzdys

Fig. 1. An example of a different level graph

\section{VILNIAUS MIESTO VIEŠŲJŲ ERDVIŲ SISTEMOS İVERTINIMAS}

Vilniaus miesto viešųjų erdvių sistema skirtingose Vilniaus miesto dalyse yra išsivysčiusi netolygiai. Pavyzdžiui, centrinejje miesto dalyje ar pacentriuose ji labiau išvystyta, čia viešųjų erdvių tinklas yra tankesnis, o kitose dalyse, ypač periferinèse, jos yra žemesnio lygio. Anot I. Alistratovaitės-Kurtinaitienès, miesto morfostruktūroje egzistuojanti miesto dalių hierarchija - senamiestis, centrinè dalis, naujieji rajonai, priemiestis - turi ir savitą viešųjų erdvių struktūrą. Šią viešųjų erdvių struktūrą atskleidžia ne tik aikštès, kurios dažniausiai yra susikertančių gatvių mazgas, ị kurị gatvèmis lengvai ir netrukdomai patenkama iš kitų miesto vietų, tačiau ir viešųjų erdvių pasiskirstymas bei jų užimamas plotas skirtingose miesto dalyse (Alistratovaité-Kurtinaitienė, 2015) (1 pav.). Taigi viešosios erdvès polistruktūriškumas yra svarbus viešosios erdvès požymis.

Vilniaus miesto savivaldybès teritorijos bendrojo plano iki 2015 metų duomenys atskleidžia, kad Vilniaus miesto savivaldybejje esančios aikš- tès, skverai, parkai, žaliosios jungtys, kapinès ir kitos viešosios erdvès užima apie 2853 hektarų plotą, kas yra apie 7,1 \% visos Vilniaus miesto savivaldybès teritorijos. Jeigu dar prijungtume Vilniaus miesto savivaldybès teritorijoje esančių miškų ir miškingų teritorijų plotines reikšmes, kurios sudaro apie $36 \%$ visos Vilniaus miesto teritorijos ploto, galima teigti, kad Vilniaus miesto žalieji plotai dengia daugiau nei du penktadalius (apie 43,1\%) visos Vilniaus miesto savivaldybès teritorijos (Vilniaus miesto savivaldybès..., 2009).

Vilniaus miesto aikštès užima mažiausią plotą iš visų Vilniaus miesto viešųjų erdvių - tik apie 10 hektarų, kas sudaro apie 0,35 \% visų Vilniaus miesto viešųjų erdvių. Panaši situacija yra ir su skverais, kurie užima vos 16 hektaru Vilniaus miesto teritorijos, t. y. apie 0,55 \% ploto. Aikščių ir skverų užimama procentinè dalis tarp visų Vilniaus mieste esančių viešųjų erdvių nesiekia net vieno procento, šios erdves sudaro tik apie $0,9 \%$ viso Vilniaus miesto teritorijos ploto. Nepaisant to, Vilniaus miesto parkai užima net apie ketvirtadali, t. y. apie 26,5 \% visų Vilniaus miesto viešųjų erdvių (756 ha). Žaliųjų jungčių užimamas plotas yra apie 618 hektarų, tai šiek tiek daugiau nei penktadalis (apie $22 \%$ ) viso viešųju erdvių užimamo ploto Vilniaus mieste. Kapinès užima apie 290 hektarus, t. y. apie 10 \% visų viešųjų erdvių. Kitos viešosios erdvès, pavyzdžiui, botanikos sodas, paplūdimiai ar viešosios erdvès, kurios savo erdvinèmis ar funkcinėmis charakteristikomis skiriasi nuo anksčiau aptartų viešųju erdvių, užima apie 1163 hektarų plotą, kas yra apie du penktadaliai (apie 40,5 \%) viso viešųjų erdvių užimamo ploto Vilniaus mieste (Vilniaus miesto savivaldybès..., 2009).

Vis dèlto gauti rezultatai atspindi tik dali informacijos apie Vilniaus miesto viešąsias erdves ir jų sistemą. Vertètų viešąsias erdves vertinti ne tik pagal jų užimamą plotą, tačiau atsižvelgti i juc pasiskirstymą, išsidèstymą skirtingose Vilniaus miesto dalyse, taip pat paieškoti priežasčių, kodèl susiklostè tokia padètis. Viešosios erdvès yra būtinos visuomenei, bet reikia nepamiršti, kad jos turi būti efektyvios, aktyvios ir lengvai pasiekiamos. Juk net geoekologinès takoskyros yra tarytum juostos, kurios jungia svarbias ekologiniu požiūriu vietoves, bet yra ir jungtys tarp kai kurių viešųjų erdvių. 


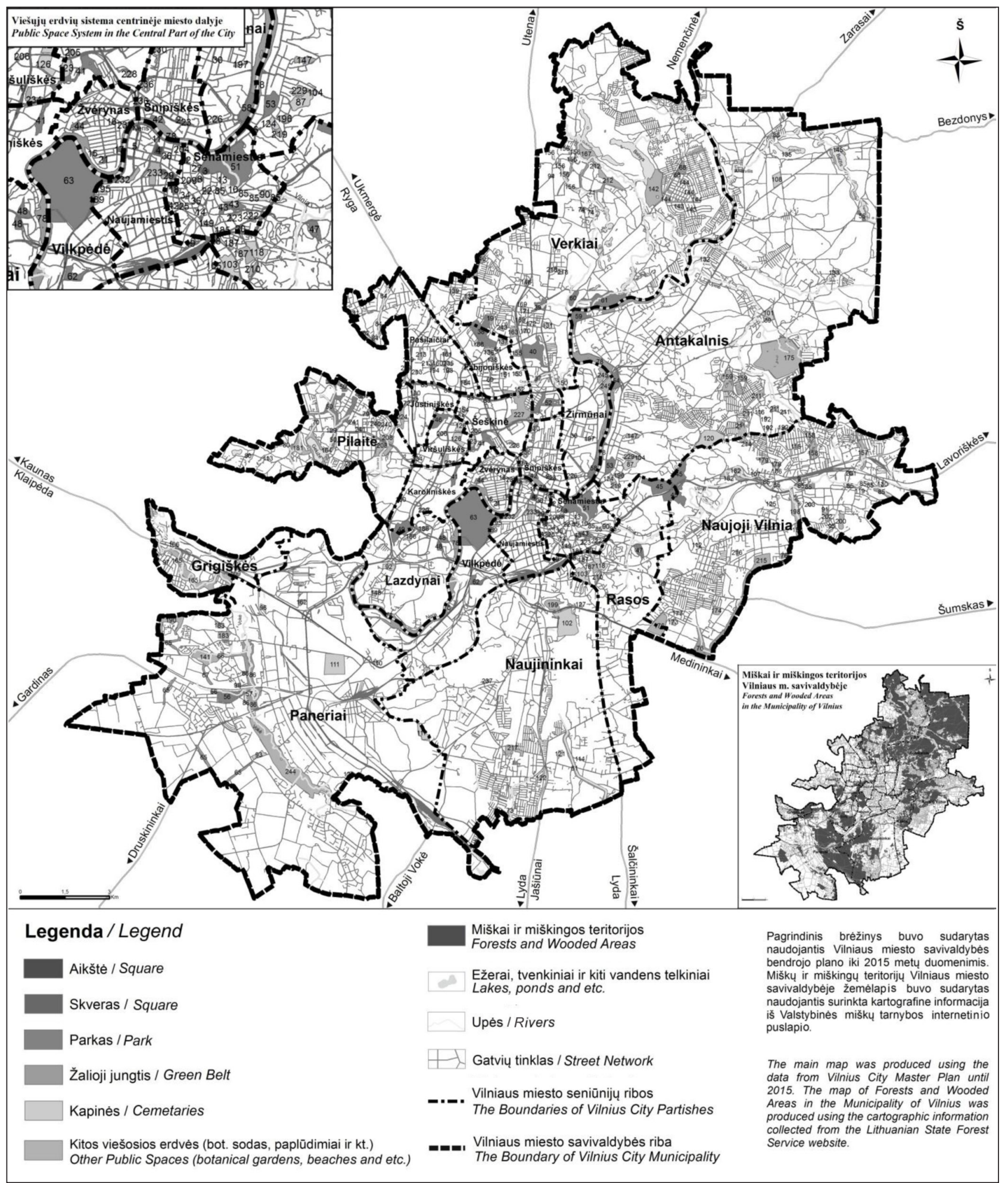

2 pav. Vilniaus miesto viešųjų erdvių sistema

Fig. 2. Vilnius Urban Public Spaces System

\section{VILNIAUS MIESTO VIEŠŲJŲ ERDVIŲ SISTEMOS ELEMENTŲ SKLAIDA}

Centrinèse miestų dalyse viešųjų erdvių skaičius yra didžiausias. Tam ittakos neturi net ir miesto dydis.
Centre tradiciškai daugiausia plètojamos viešosios erdvès. Ne išimtis ir Vilniaus miestas, kurio centrineje dalyje yra didžioji dalis koncentruoto tipo viešųjų erdvių (aikščių, skverų, kiek mažiau parkų) ir yra bene geriausiai išvystytas gatvių tinklas (1 pav.). 
Vilniaus miesto savivaldybeje yra 12 aikščių. Absoliuti dauguma aikščiu koncentruojai centrineje Vilniaus miesto dalyje (1 pav.): penkios yra Senamiesčio seniūnijoje, trys Naujamiesčio, po vieną aikštę yra Šnipiškių, Antakalnio, Viršuliškių ir tolèliau nutolusioje Naujosios Vilnios seniūnijose. Likusiose penkiolikoje seniūnijų nèra nei vienos aikštès, vadinasi, jose nèra nei vieno viešosios erdvès branduolio (Urbonaitè, 2013). Apžvelgus Vilniaus mieste esančias aikštes tampa akivaizdu, kad dauguma jų yra išsidėsčiusios centrinejje miesto dalyje. Nors iš pirmo žvilgsnio atrodo, kad kai kurios aikštès išsidèsčiusios atokiau nuo Vilniaus centrinès dalies esančiose seniūnijose, tarkime, Antakalnyje, vis dèlto jos yra centrinejje miesto dalyje, nes, pavyzdžiui, Popiežiaus Jono Pauliaus II aikštė yra piečiausioje Antakalnio seniūnijos dalyje prie pat Senamiesčio seniūnijos.

Kaip teigia I. Alistratovaitè-Kurtinaitienè, aikščių naujuosiuose rajonuose nèra arba jos yra integruotos ì komercinio komplekso struktūrą (2015). Tai tinka kalbant ir apie Vilniaus miesto aikštes, kurių nėra naujuosiuose, t. y. sovietinio laikotarpio, Vilniaus miesto rajonuose. Vis dèlto Tremtinių aikšté, esanti periferineje Naujosios Vilnios seniūnijoje, yra išskirtinis atvejis. Ši aikštè gana nutolusi nuo centro ir tikrai negali būti priskiriama prie centrinių Vilniaus miesto aikščių. Šj atveji galima paaiškinti savarankiška nuo Vilniaus miesto Naujosios Vilnios istorine raida, kadangi ilgą laiką, net iki pat XX a. vidurio, Naujoji Vilnia buvo atskiras miestas, o Vilniaus miesto dalimi tapo tik XX a. šeštajame dešimtmetyje (Zacharovas, 2014). Savarankiška istorinè raida lèmè kitokios viešųjų erdvių sistemos susiformavimą Naujoje Vilnioje, kuri dabar skiriasi nuo kitų periferinių Vilniaus miesto dalių viešųjų erdvių sistemų.

Skveru Vilniaus miesto savivaldybeje priskaičiuojama mažiausiai 24, tačiau jų skaičius gali siekti ir pusšimti, pavyzdžiui, kaip pateikiama I. Urbonaites straipsnyje „Rekreaciniu funkcijų raiškos transformacijos posovietinio miesto viešosiose erdvèse. Vilniaus atvejis“. Šio darbo autorè vadovavosi „Vilniaus miesto savivaldybès teritorijos bendrojo plano iki 2015 metų“ priedo „Gamtos vertybès, želdynai ir viešųjų erdvių sistemos duomenys" lentelès duomenimis. Remiantis jais, dauguma Vilniaus miesto skverų, kaip ir aikščių, yra susikoncentravę centrinèje miesto dalyje
(2 pav.). Senamiesčio seniūnijoje yra daugiau nei pusè visų Vilniaus mieste esančiu skverų (14). Šioje Vilniaus miesto dalyje skverai dažniausiai išsidèstę vietoje nutrupejusios istorinès urbanistinès struktūros ar buvusių kapinių. Evangelikų reformatų skveras yra vienas iš šio reiškinio pavyzdžių. Daugumos Senamiesčio seniūnijos skverų paskirtis yra memorialinè (Urbonaite, 2013). Kur kas mažiau skverų yra kitose seniūnijose, esančiose centrinèje Vilniaus miesto dalyje. Žvèryno seniūnijoje yra keturi skverai, o Naujamiesčio seniūnijoje vos trys. Po vieną skverą yra Šnipiškių, Rasų ir Žirmūnų seniūnijose.

Vilniaus miesto parkų skaičius varijuoja priklausomai nuo šaltinio, kuriuo yra remiamasi. Vienuose šaltiniuose jų skaičius nesiekia net 10, kitur priskaičiuojama ir tris kartus daugiau. Šio darbo autoriai, vadovaudamiesi „Vilniaus miesto savivaldybès teritorijos bendrojo plano iki 2015 metų“ priedo "Gamtos vertybès, želdynai ir viešųju erdvių sistemos duomenys" lentelès duomenimis, pateikia beveik tris dešimtis Vilniaus miesto parkų. Tiesa, šis skaičius gali pasirodyti gana didelis, ypač lyginant su A. Tauro leidinyje „Mūsų parkai“ išskiriamais aštuoniais Vilniaus mieste esančiais parkais (1989), tačiau per beveik tris nepriklausomybès dešimtmečius įvyko pokyčių ne tik šalies politinejje, ekonominèje ar kultūrineje srityse, tačiau ir Vilniaus miesto parkų sistemoje.

A. Tauro teigimu, dar prieš XX amžiaus 10-ąji dešimtmetị Vilniaus mieste žaliavo aštuoni parkai: Centrinis, Skulptūrų, Vingio, Verkių, Žvèryno, Markučių, Pavilnio ir „Draugystès“ (1989). Dabar tik dalis šių parkų išsaugojo ankstesnius pavadinimus (Vingio, Verkių, Markučių), o kita dalis pavadinimus pakeitè, pavyzdžiui, Centrinis parkas tapo Pilių parku, „Draugystès“ - Paroduc (Litexpo) parku. Be abejonès, per tris dešimtmečius įvyko ir daugiau pokyčių.

Vilniaus mieste esantys parkai kur kas labiau pasklidę po visą miesto teritoriją nei aikštès ar skverai (2 pav.). Bent po vieną parką yra daugumoje Vilniaus miesto seniūnijų (tik keturiose iš 21 Vilniaus m. sen. nèra parkų). Parkus priskirti konkrečiai seniūnijai sudètinga, kadangi kai kurie jų, pavyzdžiui, Lyglaukių, Pasakų, yra išsidèstę kelių seniūnijų teritorijose.

Daugiausia parkų yra didžiosiose Vilniaus miesto seniūnijose - Antakalnio ir Verkių. Panerių 
seniūnija, kuri pagal plotą yra didžiausia Vilniaus miesto seniūnija, nusileidžia Antakalnio ir Verkių seniūnijoms. Antakalnio seniūnijoje yra keturi parkai, Verkių seniūnijoje šeši, o didžiausioje Vilniaus miesto Panerių seniūnijoje - tik du.

Vilniaus miesto centrinejje dalyje esančiose seniūnijose (Senamiesčio, Šnipiškių, Žvèryno) ir Vilkpèdès bei Rasų seniūnijose galima priskaičiuoti po aštuonis devynis parkus. Lyginant su parkų kiekiu kitose Europos valstybių sostinèse, tai nèra mažai.

Sovietiniais metais ikurtuose Vilniaus miesto rajonuose (Žirmūnuose, Lazdynuose, Karoliniškèse, Viršuliškèse, Fabijoniškèse, Pašilaičiuose, o iš dalies ir Pilaiteje) yra po vieną ar du parkus, skirtus rajonų gyventojų poilsio ir rekreacijos reikmėms. Šių parkų pavadinimai dažnai sutampa su rajono, kuriame jie yra išsidèstę, pavadinimais.

Vilniaus miesto parku pasiskirstymas nulemtas istorinès Vilniaus miesto raidos. Dauguma Vilniaus miesto parkų susikoncentravę kompaktiškai užstatytoje miesto teritorijoje, kuri apima tiek centrinę Vilniaus miesto dalį, tiek sovietinio laikotarpio gyvenamuosius rajonus. Tuo tarpu periferineje Vilniaus miesto dalyje parku yra mažiau, galima sakyti, kad čia sąlyginị parkų vaidmenį atlieka mažiau žmogaus įsisavinti plotai - miškai ir miškingos teritorijos, ypač specialiosios paskirties miškų grupe (daugiausia rekreaciniai miškai, mažiau - ekosistemų apsaugos miškai). Dalis šių miškų yra didelio rekreacinio potencialo, t. y. pritaikomi intensyviam naudojimui bei yra ịvardijami kaip miško parkai (Vilniaus miesto savivaldybès..., 2009).

Vilniaus mieste yra 27 žaliosios jungtys. Jos, kaip ir parkai, pasklidusios po visą Vilniaus miesto teritoriją (1 pav.). Pagal užimamą plotą Vilniaus miesto žaliosios jungtys yra kategorizuojamos smulkiau ì pagrindinių viso miesto želdynų, rajoninių želdynų ir vietinių želdynų jungtis.

Kapinių Vilniaus mieste yra beveik pusšimtis (48), o kai kurių autorių duomenimis, pavyzdžiui, geografo D. Liutiko, ir šiek tiek daugiau nei pusšimtis (52). Tiesa, oficialus veikiančių kapinių skaičius tesudaro tik tris penktadalius visų kapinių; kitos kapinès yra neveikiančios ar riboto naudojimo (laidojimo). Visų Vilniuje esančių kapinių plotas siekia apie 258 hektarus
(Liutikas, 2017). Daugiausia kapinių yra periferinėse Vilniaus miesto seniūnijose - Antakalnyje, Naujojoje Vilnioje, Paneriuose, Naujininkuose (2 pav.). Tiesa, Verkių seniūnija, trečia pagal plotą Vilniaus mieste, yra išimtis, kadangi turi tik dvi kapines. Kapinių gausą minètose seniūnijose būtų galima paaiškinti šių seniūnijų geografine padètimi, kadangi jos yra periferijoje, kur daugiau laisvos neužstatytos teritorijos bei mažesnis gyventojų tankumas. Tai galima paaiškinti ir dabartine kultūrine tradicija kapines įrengti miestu ar miestelių pakraščiuose, t. y. periferijoje (Liutikas, 2017), ar už miesto, kaip buvo pasielgta su Karveliškių kapinėmis. Svarbų vaidmenị atlieka ir šių seniūnijų plotas. Nevertètų pamiršti ir tokios detalès, kad anksčiau šios teritorijos nepriklausė Vilniaus miestui, o buvo atskiros gyvenvietés, kaimai.

Vilniaus centrinejje dalyje 1801 metais buvo irrengtos seniausios Vilniaus mieste Rasų kapinès, vèliau Bernardinų (1810 m.) (Liutikas, 2017). Prie centrinès Vilniaus miesto dalies kapinių taip pat yra paminètinos ir Liepkalnio stačiatikių kapinès, esančios Rasų seniūnijoje. Toliau nuo centro nutolusiose Šeškinès, Justiniškių, Lazdynų, Viršuliškių, Pilaitès ar Grigiškių seniūnijose yra vienos ar dvejos kapinès. Dauguma šių kapinių buvo įkurtos XX amžiuje.

Šiame darbe dar aptartos tokios viešosios erdvès kaip paplūdimiai, botanikos sodas ir viešosios erdvès, kurių statusas nèra aiškiai įvardytas, dažniausiai vadinamos plačia želdyno sąvoka. Tokiu erdvių yra labai daug, jos išsidèstę visame Vilniaus mieste, ju yra kiekvienoje Vilniaus miesto seniūnijoje (2 pav.). Tad būtų netikslinga šias erdves aptarti detaliau, jos nepatenka tarp pagrindiniu šio darbo viešųjų erdvių (aikščių, skverų, parkų, gatvių tinklų).

Daugumos šių erdvių plotas yra labai mažas, jos atlieka lokalų vaidmenį viešųjų erdvių sistemoje. Tačiau tokios erdvès kaip Kairènų botanikos sodas, Šeškinès ozas ar Vokès slènio želdynas dèl santykinai didelio užimamo ploto atlieka kur kas svarbesnị vaidmeni. Svarbi ir jų lokacija, ypač Šeškinès ozo. Kairènų botanikos sodas išsiskiria daugiafunkciškumu, jis atlieka ne tik tradicines botanikos sodo funkcijas (mokslinę, mokomąją ar apsauginę) (Šaltenytė, 2014), tačiau ir rekreacinę, kuri sudaro sąlygas įsilieti $\mathfrak{i}$ Vilniaus miesto viešųjų erdvių sistemą. 
Vilniaus miesto žaliosios jungtys, kapinès ir kitos viešosios erdvès yra pasklidusios po visą miesto teritoriją. Žaliųjų jungčių ir kapinių skaičius auga tolstant nuo Vilniaus miesto centro link periferijos, o kitų viešųjų erdvių (botanikos sodas, paplūdimiai ir kt.) skaičius išlieka panašus tiek centre, tiek artejjant link periferijos.

Kaip parodè prieš tai aptarti viešųjų erdvių tipai ir parengtas Vilniaus miesto viešųjų erdvių sistemos žemèlapis (2 pav.), tankiausias gatviu tinklas yra Vilniaus miesto centrinèje dalyje. Iš visos centrinès dalies išsiskiria Vilniaus senamiesčio gatvių tinklas, kuris yra tankiausias visame mieste. Centrinès Vilniaus miesto dalies viešųų erdvių potencialas dažnai priklauso nuo jų ryšių su pagrindinèmis gatvėmis, pavyzdžiui, Pilies gatve ar Gedimino prospektu (Bučys, 2010).

Sovietiniais metais suformuotų gyvenamųjų rajonų gatvių tinklas yra pakankamai retas. Tačiau kalbant apie šių rajonų pėsčiųjų takų, vedančių ì lokalius šių rajonų centrus, tinklą, situacija yra priešinga - šiuose rajonuose jis yra itin tankus (Bučys, 2010). Artèjant link periferijos, Vilniaus miesto gatvių tinklas reteja, tačiau yra ir išimčių. Pavyzdžiui, Naujoji Vilnia turi pakankamai tankų gatvių tinklą, susiklosčiusị dèl skirtingos istorinès raidos, ar Balsių gyvenviete, kurios gatvių tinklas taip pat nèra retas. Tokio gatviu tinklo susiformavimą galejjo nulemti ir tai, kad Balsiai yra nuosavų gyvenamųjų namų kvartalas, tad jo planavimas skiriasi nuo sovietinio laikotarpio gyvenamujų rajonų.

Vilniaus miesto gatvių statusas, jų svarba labai skiriasi, nors gatvès yra panašios konfigūracijos bei plotinès reikšmès. Vienas tokių pavyzdžiu yra i šiaurę nuo Konstitucijos prospekto lygiagrečiai besidriekiančios Kalvarijų, Giedraičių ir Kernavès gatvės, atliekančios skirtingus vaidmenis Vilniaus miesto gatvių tinkle. Pavyzdžiui, Kalvarijų gatvè yra svarbi šiaurès-pietų susisiekimo arterija visame mieste, o Giedraičių gatvė yra svarbi tik lokaliai (Bučys, 2010). Galima teigti, kad Vilniaus miesto gatvių statusas yra nevienodas, tačiau norint išsamiau jị aptarti reikètų atlikti naują tyrimą.

\section{VILNIAUS MIESTO VIEŠŲJŲ ERDVIŲ SĄSAJOS}

Ryšių tarp subjektų kaip tam tikros struktūros samprata socialiniuose moksluose yra atejusi iš matematinès grafų teorijos (Newman, 2003), kurios teorinemis gairemis yra remiamasi šiame skyriuje. Itvertinti Vilniaus miesto viešųjų erdvių ryšius yra pakankamai sudetinga ir subjektyvu, kadangi tai dažniausiai priklauso nuo autoriaus pasirinkto tyrimo aspekto $(-\mathrm{u})$.

Nagrinejjant viešąsias erdves svarbu tyrinèti sąsajas (Daniulaitis, Dimindavičiūtè, 1999). Todèl siekiant pavaizduoti Vilniaus miesto viešųų erdvių ryšius buvo parengta Vilniaus miesto viešųjų erdvių sąsajų schema (modelis) (3 pav.). Schema atskleidžia Vilniaus miesto viešujų erdvių (aikščių, skverų, parkų, žaliųjų jungčiu, kapinių ir kt.) tarpusavio jungtis, kurios yra pateikiamos įvertinus Vilniaus miesto gatvių tinklą. Gatvių tinklo sudètingumas lèmé, kad šį svarbų viešųjų erdvių elementą buvo pasirinkta perteikti per jungtis, tačiau ne per tiesiogini jo atvaizdavimą, kaip buvo pasielgta su kitais viešųjų erdvių tipais.

Vilniaus miesto centrinèje dalyje viešųjų erdvių yra daugiausia, o šios miesto dalies gatvių tinklas yra tankiausias visame Vilniaus mieste. Tai leidžia teigti, kad ši Vilniaus miesto dalis išsiskiria viešųjų erdvių sąsajų jungčių gausa. Viešųjų erdvių sąsajų jungtys čia yra trumpos, jų daug, jos tankiai susikoncentravusios, ypač senamiestyje. Galima išskirti tam tikrą Vilniaus miesto centrinès dalies viešųjų erdvių koncentracijos branduolį, kuris smulkiau gali būti padalytas $\mathfrak{i}$ vidinị ir išorinị. Vidinis branduolys daugiausia apima Vilniaus senamiesčio viešąsias erdves, kurios pagal plotą yra smulkios, o išorinis branduolys apima likusias viešąsias erdves, kurių plotinès reikšmès yra didesnès, tačiau koncentracija vienoje vietoje yra mažesnè nei prieš tai aptartųjų, jos labiau pasklidusios po teritoriją. Šis branduolys daugiausia apima centrinę, vakarinę ir šiaurès vakarinę Vilniaus miesto dalis, t. y. kompaktiškai užstatytą Vilniaus miesto teritoriją.

Tolstant nuo Vilniaus miesto centrinès dalies, viešųu erdvių sąsajų jungtys silpnèja - mažeja jų skaičius ir kinta parametrai, atsiranda ilgesnès jungtys tarp viešųjų erdvių. Viešųjų erdvių skaičius yra mažesnis, jos labiau pasklidusios, o gatvių tinklas silpnai išvystytas. Didesnių viešųjų erdvių sankaupų (branduolių) nèra, mažesni branduoliai atsiranda tik Vilniaus miesto periferijoje. Ypač išsiskiria rytineje Vilniaus miesto dalyje esantis ryškus Naujosios Vilnios viešųų erdvių branduolys, čia susikoncentravę daugiau viešųjų erdvių, o 


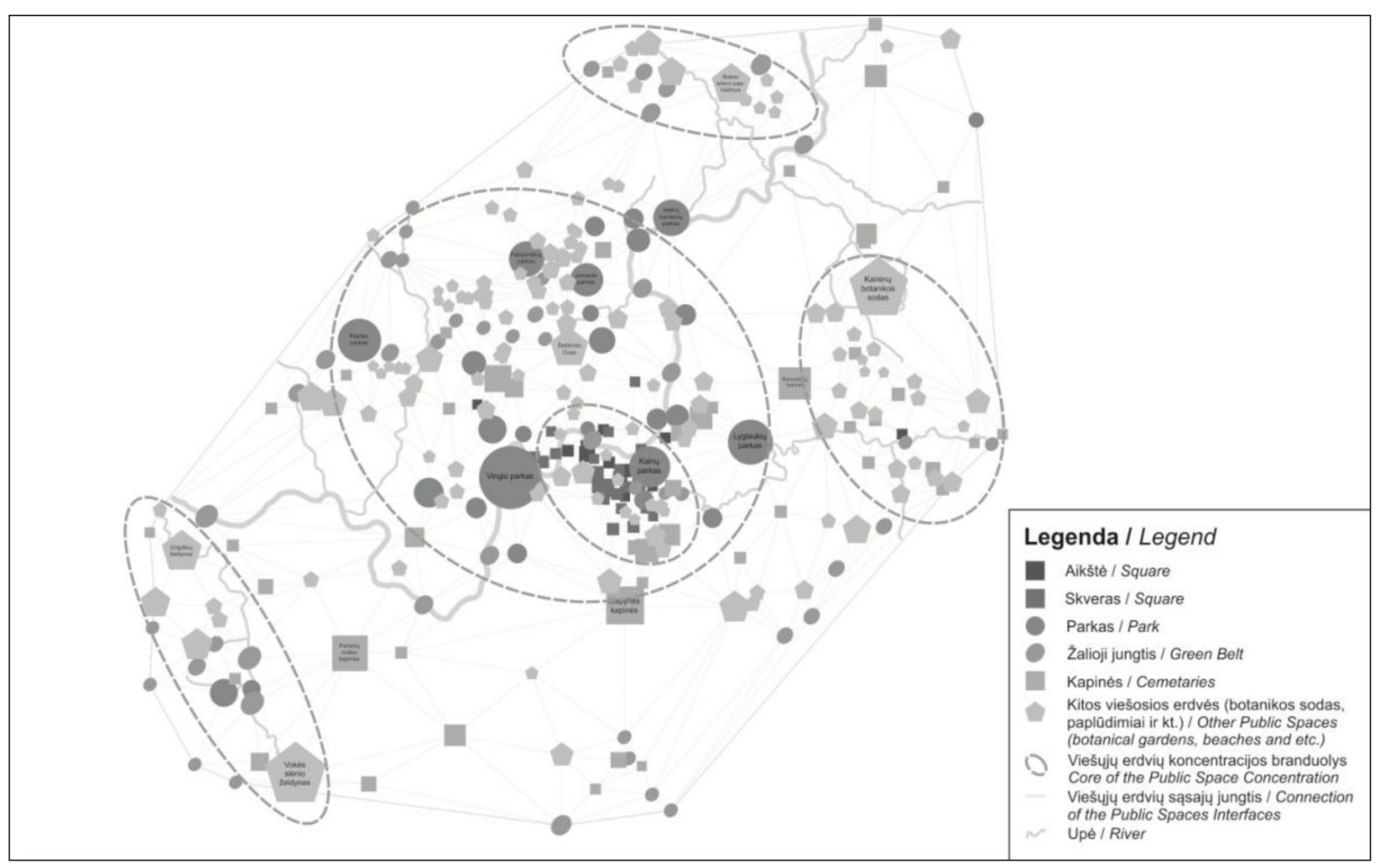

3 pav. Vilniaus miesto viešųjų erdvių sąsajų schema

Fig. 3. Scheme of Vilnius Urban Public Spaces Interfaces

gatvių tinklas yra tankus. Dar du tokius viešųjų erdvių koncentracijos branduolius galima išskirti šiaurineje ir pietvakarineje Vilniaus miesto dalyse. Šiuos branduolius galima ịvardyti kaip Balsių ir Panerių-Grigiškių viešųjų erdvių koncentracijos branduolius. Čia gatvių tinklas nèra toks tankus kaip Naujosios Vilnios branduolyje; gatvių tinklas sutankèja tik kai kuriose dalyse, tačiau šią „netektị “ finansuoja didesni viešųjų erdvių koncentracijos centrai. Šiuos tris branduolius sąlyginai galima laikyti trimis atskiromis posistemis Vilniaus miesto viešųjų erdvių sistemoje.

Vilniaus miesto viešosios erdvès susijusios nevienodais ryšiais. Centrinejje Vilniaus miesto dalyje viešųjų erdvių sąsajų jungtys yra stipriausios, kadangi čia viešųjų erdvių koncentracija didžiausia, o gatvių tinklas tankiausias. Vilniaus senamiestis išsiskiria stipriausiomis viešųjų erdvių jungtimis, o likusioje kompaktiškai užstatytoje Vilniaus miesto teritorijoje šios jungtys yra silpnos. Artejant link Vilniaus miesto periferinès dalies šios jungtys silpnejja, išryškejja tik keli didesnès viešųjų erdvių koncentracijos centrai su tankesniu gatvių tinklu, kuris sustiprina šių viešųjų erdvių sąsajų jungtis.

\section{VILNIAUS MIESTO VIEŠŲJŲ ERDVIŲ SISTEMOS PROBLEMINIAI AREALAI}

Nevienodas Vilniaus miesto viešųjų erdvių sistemos elementų pasiskirstymas lemia viešųjų erdvių trūkumą: kai vienose miesto dalyse jų trūksta, o kitose yra pakankamai. Tokius arealus, kuriuose jaučiamas viešųjų erdvių trūkumas, galima laikyti probleminiais arealais. Vilniaus mieste tokiu arealų yra nemažai, jų išskyrimas gali kelti problemų. Dèl šios priežasties viešųjų erdvių trūkumą buvo pasirinkta analizuoti remiantis Vilniaus miesto seniūnijų vienetais. Prieš apžvalgą buvo atlikti skaičiavimai, apėmę kiekvienos Vilniaus miesto seniūnijos ịvertinimą penkiabalejje skaleje. Kiekvienai Vilniaus miesto seniūnijai buvo paskaičiuoti balai, gauti išvedus vidurkị iš viešųjų erdvių užimamo ploto dalies seniūnijoje balo ir gyventojų skaičiaus balo. Kuo mažesnis balas buvo paskirtas Vilniaus miesto seniūnijai, tuo joje buvo nustatytas didesnis viešųjų erdvių trūkumas.

Atlikus skaičiavimus nustatyta, kad mažiausią balą $(1,5)$ surinko Naujininkų ir Verkių seniūnijos, šiek tiek daugiau - Antakalnio, Lazdynų, Naujosios 
Vilnios, Pašilaičių ir Žirmūnų seniūnijos (po 2 balus). Antakalnio, Naujininkų, Naujosios Vilnios ir Verkių seniūnijos yra vienos didžiausių Vilniaus mieste tiek pagal užimamą plotą, tiek pagal gyventojų skaičių, tačiau šiose seniūnijose esančių viešųjų erdvių užimamas plotas svyruoja nuo 2,9 \% Naujininkų seniūnijoje iki 7,8 \% Naujosios Vilnios seniūnijoje. Jos atsilieka nuo kitų seniūnijų, jų rezultatai yra prasčiausi. Šios seniūnijos išsiskiria dideliu plotu, todèl daugiau turètų būti ir viešųjų erdvių. O taip nèra, nes didelius šių seniūnijų plotus dengia miškai ar miškingos teritorijos, kurių dauguma nèra pritaikyta rekreacinei veiklai (išimtis galbūt būtų tik rekreaciniai miškai). Gyventojų skaičius šiose seniūnijose svyruoja nuo 31 tūkst. Naujininkų ir Naujosios Vilnios seniūnijose iki 42 tūkst. Verkių seniūnijoje, vadinasi, turètų būti daugiau ir viešųjų erdvių.

Lazdynų ir Pašilaičių seniūnijose yra šiek tiek kitaip. Nors pagal plotą tai vidutinio dy- džio seniūnijos (5-15 $\left.\mathrm{km}^{2}\right)$, kuriose gyventoju skaičius svyruoja nuo 31 iki 33 tūkst., tačiau viešosios erdvès irgi dengia nepakankamą plotą. Žirmūnų seniūnijoje gyvena itin daug žmonių (apie 46 tūkst.), tai gausiausiai apgyvendinta seniūnija visame Vilniaus mieste. Nors Žirmūnų seniūnijos bendrojo ploto ir jị dengiančių viešųų erdvių ploto, siekiančio apie 12,3\%, santykis yra neblogas, tačiau gyventojų skaičius lemia, kad yra kur kas didesnis viešųjų erdvių poreikis nei dabar turima viešųjų erdvių.

Po 2,5 balus surinko Fabijoniškių, Justiniškių, Karoliniškių ir Naujamiesčio seniūnijos. Justiniškių, Karoliniškių ir Naujamiesčio seniūnijos pasižymi panašiais rodikliais. Šiose seniūnijose gyventojų skaičius svyruoja apie 23-27 tūkst., pagal plotą jas galima laikyti smulkaus dydžio seniūnijomis $\left(0-5 \mathrm{~km}^{2}\right)$; viešųjų erdvių užimamas plotas nėra pakankamas, jis siekia apie 7,6 \% Justiniškių ir 8,6 \% Karoliniškių seniūnijose. Tačiau

2 lentelè. Viešųjų erdvių trūkumas Vilniaus miesto seniūnijose

Table 2. Lack of public spaces in Vilnius city elderships

\begin{tabular}{|c|c|c|c|c|c|}
\hline $\begin{array}{l}\text { Seniūnijos pavadinimas } \\
\text { Name of eldership }\end{array}$ & $\begin{array}{l}\text { Viešujų erdvių užimamo } \\
\text { ploto dalis seniūnijoje \% } \\
\text { Area occupied by public } \\
\text { spaces in elderships, \% }\end{array}$ & $\begin{array}{l}\text { Balas } \\
\text { Score }\end{array}$ & $\begin{array}{l}\text { Gyventojų } \\
\text { skaičius } \\
(2011 \mathrm{~m} .) \\
\text { Population in } \\
2011\end{array}$ & $\begin{array}{l}\text { Balas } \\
\text { Score }\end{array}$ & $\begin{array}{c}\text { Galutinio } \\
\text { ivertinimo } \\
\text { balas } \\
\text { Final rating } \\
\text { score }\end{array}$ \\
\hline Antakalnio seniūnija & 5,5 & 2 & 38940 & 2 & 2 \\
\hline Fabijoniškių seniūnija & 11,5 & 3 & 39759 & 2 & 2,5 \\
\hline Grigiškių seniūnija & 10,2 & 3 & 12000 & 4 & 3,5 \\
\hline Justiniškių seniūnija & 7,6 & 2 & 27462 & 3 & 2,5 \\
\hline Karoliniškių seniūnija & 8,6 & 2 & 27270 & 3 & 2,5 \\
\hline Lazdynų seniūnija & 7,6 & 2 & 31097 & 2 & 2 \\
\hline Naujamiesčio seniūnija & 8,2 & 2 & 23232 & 3 & 2,5 \\
\hline Naujininkų seniūnija & 2,9 & 1 & 31171 & 2 & 1,5 \\
\hline Naujosios Vilnios seniūnija & 7,8 & 2 & 31933 & 2 & 2 \\
\hline Panerių seniūnija & 5,4 & 2 & 7740 & 5 & 3,5 \\
\hline Pašilaičių seniūnija & 5,7 & 2 & 33056 & 2 & 2 \\
\hline Pilaitės seniūnija & 12,6 & 3 & 20320 & 3 & 3 \\
\hline Rasų seniūnija & 6,5 & 2 & 10597 & 4 & 3 \\
\hline Senamiesčio seniūnija & 23,3 & 5 & 19447 & 4 & 4,5 \\
\hline Šeškinės seniūnija & 17 & 4 & 31333 & 2 & 3 \\
\hline Šnipiškių seniūnija & 8,6 & 2 & 15342 & 4 & 3 \\
\hline Verkių seniūnija & 6,6 & 2 & 42179 & 1 & 1,5 \\
\hline Vilkpèdès seniūnija & 21,8 & 5 & 21346 & 3 & 4 \\
\hline Viršuliškių seniūnija & 19,1 & 4 & 14733 & 4 & 4 \\
\hline
\end{tabular}


šiose seniūnijose nèra daug gyventojų. Skirtinga situacija yra Fabijoniškių seniūnijoje, kurioje yra beveik 40 tūkst. gyventojų, todèl juntamas didesnis viešųjų erdvių poreikis, kurị patenkina iš dalies nemažas viešųjų erdvių plotas, siekiantis apie $11,5 \%$ visos seniūnijos teritorijos.

Po tris balus surinko Pilaitès, Rasų, Šeškinès ir Šnipiškių seniūnijos. Rasų ir Šnipiškių seniūnijos napasižymi dideliu gyventojų skaičiumi. Šeškinès seniūnijos situacija yra viena geresnių, kadangi joje viešosios erdvès užima net $17 \%$ visos seniūnijos teritorijos ploto (ypač svarbus indèlis yra Šeškinès ozo, užimančio apie pusę viso viešųjų erdvių dengiamo ploto Šeškinès seniūnijoje). Vis dèlto šios seniūnijos gyventojų skaičius, viršijantis 31 tūkst., sumažina galutini šios seniūnijos ịvertinimo balą.

Grigiškių, Panerių ir Žvèryno seniūnijos surinko po 3,5 balus. Šios trys seniūnijos išsiskiria vienu mažiausiu gyventojų skaičiumi iš visų Vilniaus miesto seniūnijų, jis siekia 7 tūkst. Panerių seniūnijoje ir 12 tūkst. Grigiškių seniūnijoje. Nors Panerių seniūnija pagal plotą yra pati didžiausia visame Vilniaus mieste, tačiau pati mažiausia pagal gyventojų skaičių. Nors šios seniūnijos plotus dengia vos $5,4 \%$ viešųjų erdvių, tačiau dideles teritorijas užima miškai ir miškingos vietovès, o mažas šios seniūnijos gyventojų skaičius nesukuria didelio viešųjų erdvių poreikio. Dèl mažo gyventoju skaičiaus (apie 11 ir 12 tūkst.) ir dèl viešųjų erdvių užimamo ploto dalies (apie 10,2 ir $11,1 \%)$ pakankamai aukštu balu buvo ịvertintos Žvèryno ir Grigiškių seniūnijos.

Keturiais balais buvo įvertintos tik dvi seniūnijos - Vilkpèdès ir Viršuliškių. Šios seniūnijos nors ir nepasižymi dideliu gyventojų skaičiumi (atitinkamai apie 21 tūkst. ir apie 14 tūkst.), tačiau viešųjų erdvių užimamas plotas yra didelis. Viršuliškių seniūnijoje yra didelès Sudervès kapinès, o Vilkpèdès seniūnijoje - 162 hektarų ploto Vingio parkas.

Aukščiausias vertinimo balas $(4,5)$ buvo paskirtas tik vienai seniūnijai - Senamiesčio. Šios seniūnijos plotas yra sąlyginai nedidelis, pati seniūnija priskiriama prie mažesnių, gyventojų skaičius nesiekia 20 tūkst. Apie 23,3 \% seniūnijos ploto užima viešosios erdvés, t. y. beveik ketvirtadalis visos seniūnijos teritorijos. Senamiesčio seniūnijoje yra Kalnų parkas, užimantis apie 33 hektarus, jis sudaro apie pusę viso šios seniūnijos užimamo viešųjų erdvių ploto.
Viešųų erdvių sistema neatsiejama nuo socialinių struktūrų išvystymo (Burinskienè, UšpalytèVitkūniené, 2006). D. Makutènienè ir R. Žiūrienè (2006) teigia, kad negalima projektuoti viešųjų erdvių neatsižvelgiant ị visą jų sistemą. Todèl svarbu pabrèžti, kad atlikus vertinimą paaiškejjo, jog vienose Vilniaus miesto seniūnijose egzistuoja viešųjų erdvių trūkumas, o kitose šio trūkumo nèra. Vis dèlto ši apžvalga nèra pagrịsta, kadangi kai kuriuos veiksnius sunku ivvertinti, o jie gali daryti didelę įtaką. Pavyzdžiui, kaimynystès efektas, kai vienose seniūnijose trūksta viešųų erdvių, tačiau kaimynineje seniūnijoje jų yra pakankamai daug. Pavyzdžiui, Naujamiesčio seniūnijoje nèra daug viešųjų erdvių, tačiau kaimyninėse Senamiesčio ar Vilkpèdès seniūnijose yra didesnių viešųjų erdvių, kurios atsveria Naujamiesčio seniūnijos viešuju erdvių trūkumą. Kitas veiksnys yra miškai ir miškingos teritorijos, kurias mielai renkasi gyventojai, norèdami pailsèti ir pabėgti nuo miesto šurmulio. Arčiau gyvenamosios vietos esantis miškelis, nors ir ne visai nepritaikytas rekreacijai, yra paklausesnis, nei toliau esantis parkas. P. Juškevičius pabrèžia, kad mieste svarbi kokybiškesnè rekreacinè aplinka (2006). Be abejo, gali būti ir išimčių. Kad nebūtų didelio skirtumo tarp didžiųjų ir mažųjų seniūnijų, reikètų imtis sprendimų ir veiksmų pritaikant teritorijas poilsiui ir rekreacijai, t. y. ju konvertavimo í viešąsias erdves, taip padidinant viešųjų erdvių plotines reikšmes seniūnijose, kuriose jų trūksta.

\section{IŠVADOS}

1. Miestų viešųjų erdvių sistemų tyrimai yra nepakankamai kompleksiškai plètojama tyrimų kryptis Lietuvoje. Reikalingas požiūris, kad viešosios erdvès yra tampriai susijusios, stiprius vidinius ryšius turintys kompleksiškos sistemos elementai. Tai galètų turèti ịtakos planuojant miestu erdves, plètojant miestų viešųjų erdvių sistemas ir atskleidžiant ne taškiní, o sistemini požiūrị $\mathfrak{i}$ viešąsias erdves.

2. Vieningos ir išgrynintos viešosios erdvès sampratos nebuvimas lemia ginčus ir diskusijas, nes viešai nesutariama, kokias erdves vertètų laikyti viešosiomis (nors LR planavimo įstatymas numato ypač plačią sampratą), o kurių ne. Jeigu šis klausimas būtų išspręstas, tai ne tik padètų išvengti minètų ginčų, tačiau prisidètų ir prie viešųjų 
erdvių bei su jomis susijusių tyrimų intensyvumo, taip pat minètu erdviu populiarinimo.

3. Netolygus viešųjų erdvių pasiskirstymas Vilniaus mieste pasireiškia tuo, kad centrinèje miesto dalyje jų koncentracija yra didesnè, o "miegamuosiuose“ priemiesčiuose ar sovietinio laikotarpio gyvenamuosiuose rajonuose jų yra mažiau (tik Vilniaus m. sav. „satelitiniuose“ miestuose pasitaiko pavienių aktyvių viešųjų erdvių), tačiau šių skirtumų mažinimas suteiktų naujas rekreacijos ir poilsio galimybes Vilniaus miesto gyventojams ir prisidètu prie gyvenimo kokybès gerinimo.

4. Probleminiuose Vilniaus miesto arealuose, pasižyminčiuose viešųjų erdvių trūkumu, turètų būti imamasi konkrečių sprendimų ir veiksmų, nuo teritorijų pritaikymo rekreacinėms reikmėms iki jų konvertavimo į viešąsias erdves, kad ateityje pavyktų pasiekti tolygesnị viešųjų erdvių pasiskirstymą mieste, kadangi jų trūkumas blogina miesto bendruomenès gyvenimo, darbo ir veikimo erdvę bei kokybę.

5. Siekiant išlaikyti funkcionuojančių Vilniaus miesto viešųjų erdvių sistemą, būtina toliau ją plètoti, nes tik taip bus užtikrintas jos pilnavertis funkcionavimas ateityje, tik taip bus galima ją praturtinti ne tik parkų stiliaus viešosiomis erdvėmis, bet kelių ir kitų infrastruktūrų tiesinėmis viešosiomis erdvèmis.

Gauta 20181029

Priimta 20190118

\section{LITERATŪRA}

1. Alistratovaité-Kurtinaitienė I. 2015. Aikštè kaip urbanistinès erdvès tipas. Tarp socialinès funkcijos ir erdvinių dimensijų. Acta Academiae Artium Vilnensis. 76: 71-103.

2. Bučys J. 2010. Lokalių centrų vieta ir vaidmuo hierarchinèje didmiesčio centrų sistemoje: Vilniaus pavyzdys. Urbanistika ir architektūra. 34(2): 98-105.

3. Burinskienè M., Ušpalytė-Vitkūnienè R. 2006. Analysis of the dynamics of walking distances to public transport routes and its influence on housing prices. Journal of Civil Engineering and Management. 12(3): 261-267.

4. Buivydas R. 2010. Viešujų erdvių transformacija Lietuvos miestuose. Logos. 66: 132-141.

5. Butkus T. S. 2007. Kultūrinès miesto funkcijos potencialas ir jo raiškos formos urbanistinejje struktūroje. Urbanistika ir architektūra. 31(2): 87-95.
6. Butkus T. S. 2009. Urbanistinè stigma: miesto viešoji erdvè. Iš: Miestu viešosios erdvès. Kürybiškumas ir menine intervencija. 23-27.

7. Butkus T. S. 2011. Miestas kaip įvykis. Urbanistine kultūriniu funkciju studija. Kaunas: Kitos knygos.

8. Butkus T. S. 2015. Urbanistinè viešosios erdvès tipologija ir jos elementai sovietmečio Klaipédoje. Acta Academiae Artium Vilnensis. 76: 117-138.

9. Characteristics and Guidelines of Great Public Spaces. https://www.planning.org (žiūrèta 201704-13).

10. Daniulaitis G. J., Dimindavičiūtè D. 1999. Miesto žaliųjų jungčių planavimo problemos. Urbanistika ir architektūra. 23(4): 176-187.

11. Gehl, J. 2011. Life between Buildings: Using Public Space. Island Press.

12. Gehl J., Svarre B. 2013. How to Study Public Life. Island Press.

13. Gražulevičiūtè-Vileniške I. Ražauskaitė A., Ažukaitè L., Bartininkaitė V., Kulbokaitè L., Kameneckas J. 2011. Darnaus vystymosi principais paremtas kraštovaizdžių formavimas urbanizuotose teritorijose. Miestu želdynu formavimas. 1(8): 52-65.

14. Gregory D., Johnston R., Pratt G., Watts M., Whatmore S. 2009. The Dictionary of Human Geography. 5Th Edition. Hobokenas: Wiley-Blackwell.

15. Grunskis T. 2002. Miesto visuomeninių erdviụ sistema: kai kurios teorinès prielaidos. Urbanistika ir architektūra. 26(3): 137-145.

16. Grunskis T. 2009. Apie kai kurias šiuolaikines aikščių formavimo tendencijas Lietuvoje. Urbanistika ir architektūra. 33(3): 135-144.

17. Grunskis T. 2013. Miesto viešujų erdvių sistemos samprata ir formavimo modeliai. Acta Academiae Artium Vilnensis. 71: 127-138.

18. Grunskis T., Mankus M. 2013. Miesto viešujų erdvių sistema postkomunistinèje sociokultūrinèje aplinkoje. Urbanistika ir architektūra. 37(3): 210-217.

19. Gruževskis B. Šabanovas S. 2017. Lithuanian border regions - development of the periphery. Advances in European Borderlands Studies. German and European Studies of the Willy Brandt Center. 7(2): 259-278.

20. Inclusion Through Access to Public Space. http:// www.unesco.org (žiūrèta 2017-04-13).

21. Juškevičius P. 2002. Vilniaus miesto planavimo ir plètros raida. Urbanistika ir architektūra. 26(4): 161-168.

22. Juškevičius P. 2003. Miestu planavimas. Vilnius: Technika.

23. Juskevičius P. 2006. Vilniaus miesto socialinès erdvès ir deviacijos. Urbanistika ir architektūra. 2: 6977.

24. Kačerauskas T. 2011. Miesto erdvès ir kultūros naratyvai. Town Planning and Architecture. 35(2): 141146.

25. Kamičaitytè-Virbašienė J., Narvydas A. 2013. Industrinio paveldo konversija ị gyvybingas viešąsias 
žaliąsias erdves: High Line parko atvejis. Miestų želdynu formavimas. 1(10): 125-137.

26. Kavaliauskas P., Šabanovas S. 2011. New approach to functional zoning in Kaunas city. Geografija. 47(2): 125-132.

27. Lietuvos Respublikos teritoriju planavimo ìstatymo pakeitimo įstatymas. Žin., 2013, Nr. 76-3824.

28. Lietuvos Respublikos želdynu istatymas. Žin., 2007, Nr. 80-3215.

29. Liutikas D. 2017. Kapinès kaip lankytini kraštovaizdžio objektai. Soter. 62(90): 51-66.

30. Liutikas D. 2017. Lietuvos kapinių statistika: kapinių skaičius, plotas ir geografinis tipologizavimas. Soter. 63(91): 61-72.

31. Malakauskienė R., Gerikienė V. 2012. Šiuolaikinių žaliụjų erdvių formavimo tendencijos istorinių parkų kontekste. Miestų želdynų formavimas. 1(9): 108-115.

32. Makutènienè D., Žiūrienè R. 2006. Miesto parkų efektyvaus projektavimo modeliavimas. Urbanistika ir architektūra. 30(1): 51-56.

33. Mitchell M. 1995. The end of public space? Annals of the Association of American Geographers. 85(1): 108-133.

34. Newman M. E. J. 2003. The Structure and Function of Complex Network. SIAM Review, Society for Industrial and Applied Mathematics.

35. Ratti C., Raydan D., Steemers K. 2003. Building form and environmental performance: archetypes, analysis and an arid climate. Energy and Buildings. 35(1): 49-59.

36. Stauskas V. 2007. Influence of local cultural peculiarities on national and international design process and results. CIB World Building Congress Book. 989-998.

37. Šaltenytė A. 2014. Botanikos sodų valdymas ir jų funkcijos. Iš: Darnaus vystymosi strategija ir praktika. 102-110.

38. Tauras A. 1989. Mūsu parkai. Vilnius: Mokslas.

39. The Social Value of Public Spaces. https://www.jrf. org.uk (žiūrèta 2017-04-13).

40. Urbonaitè I. 2013. Rekreacinių funkcijų raiškos transformacijos posovietinio miesto viešosiose erdvėse. Vilniaus atvejis. Urbanistika ir architektūra. 37(3): 194-209.

41. Vilniaus miesto savivaldybès teritorijos bendrasis planas iki 2015 metų. 2007. Vilnius, Vilniaus miesto savivaldybès taryba.

42. Vilniaus miesto savivaldybès teritorijos bendrasis planas iki 2015 metu keitimas. 2007. Vilnius, Vilniaus miesto savivaldybès taryba.

43. Zacharovas M. 2014. Naujoji Vilnia. http://www. naujojivilnia.lt/
Tautvydas Bokmota, Simonas Šabanovas

\section{VILNIUS URBAN PUBLIC SPACES SYSTEM}

Sum mary

The objective of the article is to disclose the peculiarities of the Vilnius urban public spaces system. Due to a complex historical development of Vilnius, the Vilnius urban public spaces system experienced various influences from the West and the East. During the development of the Vilnius urban public spaces system, some parts of the system were planned and designed in line with the tendencies of planning of public spaces in one time period, while other public spaces experienced different influences and were developed during different time periods. As a result of this complex development and different influences, an uneven Vilnius urban public spaces system was formed, with its denser network of public spaces in some parts of the city and not so dense in other parts of the city. This public spaces distribution unevenness manifests in the fact that there is a higher concentration of public places in the central part of the city, especially in the Old Town, while in the "sleeping" suburbs or the Soviet-era residential areas there are less public places and the network of public places is less developed.

This article gives an overview of the concept of public space and the concept of public spaces system, as well as an opportunity to see the Vilnius urban public spaces system, its features and problematic areas from a different view. In this article it was found out that the Vilnius urban public spaces system was developed in different ways. In some parts of Vilnius, such as the Old Town, or in general, in the central part of the city, the public spaces system has more or less developed its network with more public spaces, while in other parts of Vilnius, such as the suburbs or the Soviet-era residential areas, there are fewer public spaces or a shortage of them.

Keywords: public space, system of public spaces, Vilnius, graph theory 